\title{
THE POLITICS OF CAPITALISM
}

\section{by ELLEN MEIKSINS WOOD}

Note: The following is based on a talk given in South Africa in May of this year. Before my visit, someone sent me a document entitled "The Current Economic Crisis and its Implications for South Africa," produced for a "summit" meeting of the governing alliance of the ANC, the South A frican Communist Party, and COSATU (the Confederation of South African Trade Unions). The document contained an analysis of the global crisis which was influenced by Robert Brenner's "The Economics of Global Turbulence" (discussed in the June issue of MR). Although the document's analysis was excellent and radical, intended as a critique of the assumptions underlying the government's neoliberal policies, some critics on the left argued that its own policy proposals didn't measure up to the radical analysis. The proposals were, they said, too "ameliorative," "non-transformational," and "managerial"-designed, in other words, to manage capitalism rather than to transform it. So I set out to consider, in general terms and with reference to Brenner, the problem of "non-transformational" strategies in capitalist society.

Our choice of political strategies clearly depends in large part on what we think is possible and impossible in any given conditions. And what we think is possible or impossible under capitalism obviously depends on what we think capitalism is. So let me, first, make some

Ellen Meiksins Wood's most recent book is The Origin of Capitalism (New York: Monthly Review Press, 1999). 
general observations about the nature of capitalism.

\section{Market-Dependence vs. Market-Enablement}

I've been arguing for a long time that we need to think of the capitalist market not as an opportunity but as an imperative. ${ }^{1}$ I've also argued that, as familiar as this idea may seem to Marxists, we haven't been consistent in pursuing all its implications. So let me briefly go over the basic argument again, before moving on to some of its political implications.

To understand the market as imperative, we have to understand not just how people have been able to respond to the capitalist market but how they have been forced to do so. Capitalism doesn't just allow people to avail themselves of the market in the pursuit of profit. It forces them to enter the market for the most basic conditions of survival and self-reproduction-and that applies to both workers and capitalists.

In conditions where the market has this historically unprecedented role in organizing human life and social reproduction, where people must go through the market to gain access to the most basic means of self-reproduction, the provision of all goods and services is governed by certain imperatives: the imperatives of competition, accumulation, profit-maximization, and increasing labor productivity. Under such conditions, producing use values becomes just an inconvenient medium for generating exchange value, so the primary objective of capitalist production is not the provision of goods and services at all but the self-expansion of capital. Human needs and wants are always subordinate to capital accumulation and subject to all the crises and contradictions associated with an anarchic competitive market.

No other system of class exploitation has been mediated by the market or driven by its specific imperatives. In pre-capitalist societies, the market was not the medium of self-reproduction, for either direct producers or exploiters. Direct producers were generally in possession of the means of production-typically peasants in possession of land-and exploitation took the form of direct surplus extraction by coercive force. To increase their surpluses, exploiters needed to improve not the productivity of the producers' labor so much as the effectiveness of their own coercive powers of appropriation.

Only capitalism has a system of exploitation in which exploiters depend on the market to gain access to labor power and to realize their profits. Only capitalist appropriation depends on market competition and therefore on the systematic improvement of labor productivity. Only capitalism, then, depends on constantly improving the forces of production. And only in capitalism is it necessary to grow just to stay in the same place.

Let me now formulate my argument about opportunities and imperatives in a slightly different way. Let me suggest that there's a 
fundamental difference between saying that people in capitalist society are market-dependent and saying that they're market-enabled. For example, conventional explanations of how capitalism emerged talk about how the market itself was enabled, how the market was liberated to grow and to operate freely according to its own internal principles, once impediments had been removed. ${ }^{2}$ When that happened, these arguments suggest, people were enabled, they were empowered, by the market: given unimpeded access to the market, they were enabled to pursue their own interests, to achieve prosperity by hard work or commercial skill, to supply society's needs and wants in the most efficient way.

Now you might think that Marxists would never say that people were market-enabled in that way. But Marxism too has produced its own versions of the conventional account, explaining how capitalism emerged when the bourgeoisie, or, in other versions, rural commodity producers, were freed from feudal constraints. We're told more about how people were enabled to avail themselves of market opportunities than about how they came to be market-dependent and subject to market imperatives.

This is where Brenner comes in. First, in his historical work we get a real advance in the Marxist debate on the origin of capitalism, an explanation that actually does proceed by explaining the emergence of market-dependence. And that historical insight has wider theoretical implications. So there's a very close connection between Brenner's historical account of the origin of capitalism and his analysis of the turbulence in contemporary global capitalism.

Brenner's analysis of the downturn after the long postwar boom begins with a definition of capitalism. Capitalism, he says, is a system in which "economic units-unlike those in previous historical epochs-must depend on the market for everything they need." ${ }^{3}$ His argument then proceeds on that basis, building on the premise that what distinguishes capitalism from all other social forms is the market-dependence of all economic actors, and hence their subjection to the imperatives of competition. These imperatives require strategies that lead to success in market competition-specialization, accumulation, enhancing labor-productivity, adopting low-cost techniques, moving in and out of various lines in search of profit, and so on. The result, of course, is a uniquely dynamic system which has produced a historically unprecedented tendency to self-sustaining growth and constant revolutionizing of the forces of production. But-and here is the core of economic turbulence-that very same dynamic is the source of economic downturn and stagnation, a fundamental contradiction at the heart of capitalism.

On the face of it, these propositions may not seem particularly startling. But the point is that Brenner gives market-dependence and 
subjection to competition an explanatory status distinct and apart from, even prior to, the relation between capital and labor, which Marxists generally regard as capitalism's defining characteristic (I'll come back to this later). While he certainly takes full account of the connections between market-dependence and relations of exploitation, he suggests that capitalism is, in the first instance, defined by market-dependence and subjection to competition and that there is an irreducible contradiction in the relation among capitals that is independent of the relation between capital and labor.

On this foundation, Brenner has constructed an analysis of the long postwar downturn that locates the critical mechanism of economic decline in the relation among capitals, as distinct from the relations between capital and labor. Arguing against explanations of the downturn that blame it on a profit squeeze caused by conditions too favorable to labor, he explores the irreducible contradiction in the relation among capitals which is independent of the relation with labor. In a nutshell, the argument explains how the conditions of capitalist competition inevitably lead to overcapacity, and finally to economic downturn, whatever the relations between capital and labor and even when demand is reliable and rising. Investment in fixed capital allows producers to stay in the market even when lowercost competitors enter the fray, and they can stay in even at a lower rate of profit. But the point is also that the same heavy investment means they must stay in, even just to recoup their costs, or at least it's hard to get out at the right time. So manufacturers hang on to surplus plant instead of closing it. The end result is a declining rate of aggregate profit across the industry, with wider effects throughout the whole economy. ${ }^{4}$

Many people on the left have been put off by Brenner's insistence that the fundamental contradiction that produces economic downturn is rooted in the "horizontal" relation of competition among capitals, as distinct from the "vertical" class relation between capital and labor. ${ }^{5}$ Surely, many would say, focussing on competition as against class is about as serious a crime as any Marxist could commit, and it surely has serious political implications. Some critics even suggest that this analysis marginalizes class struggle and places "competitiveness" at the center of left politics.

Since my own argument here about "non-transformational" politics is based on a conception of market-dependence like Brenner's, I want to clarify a couple of points before I proceed. In what follows, I'll try to show that, if we always look at capitalism through the lens of market-dependence, much else will become clear-for instance, about the limits of "non-transformational" politics, designed to manage capitalism rather than to transform it. I'll also have something to say about the question of competition and class struggle. But one or two points need to be cleared up first about the notion of "horizontal" 
relations, though I'll come back later to look at it more closely.

To begin with, we have to set aside some false oppositions. It's not the market instead of class exploitation. It's not competition instead of accumulation. It's not the sphere of circulation instead of the sphere of production. Competition plays a central role in capitalist accumulation because capitalism is in its essence a system of market-dependence, a system in which the sphere of circulation is directly implicated in the sphere of production and in relations of exploitation as it is in no other mode of production. This market-dependence is rooted in a specific system of property relations, a system in which access to the means of production and appropriation is itself mediated by the market. And capitalism's specific imperatives of accumulation are the consequence of marketdependence.

This is why it's not enough to say, as some of Brenner's critics have done (including John Foster in the June issue), that the primacy he gives to competition is contrary to Marx, who insists that competition doesn't cause capitalism's laws of motion but is simply their external manifestation in the movements of individual capitals. The point is that no other social form has laws of motion that work through the mechanisms of competition. No other social form is subject to the imperatives of accumulation and innovation, which are driven by competition. And competition is the mechanism of capitalism's basic laws of motion because in capitalism, as in no other system, the irreducible condition of access to the means of self-reproduction is market-dependence and subjection to market imperatives. We can't even understand capital's perennial efforts to circumvent competition without taking account of that irreducible condition of marketdependence and the competitive imperatives that go with it.

To put it another way, there is a distinctively Marxist way of focussing on the market and competition, which I've tried to identify in a kind of shorthand by talking about the difference between market opportunities and market imperatives, or market-enablement and market-dependence.

\section{Left Strategies of Market-Enablement}

What, then, are the political consequences of thinking in terms of market-enablement instead of market-dependence? We can find at least a preliminary answer in today's dominant economic strategies, which even on the left seem to be based on the principle of marketenablement. In one way or another, they seem to assume that what we need to do is somehow facilitate market opportunities, to enable: the market, or to enable people to take the best advantage of it. What they never touch is the conditions of market-dependence.

Let's take a quick look at the two main economic strategies that have dominated left thinking for quite a while. First, we have so-called 
counter-cyclical—or, more specifically, Keynesian-policies intended to regulate the capitalist economy, to smooth out its business cycles by means of state intervention. These obviously aren't exclusive to the left, but they've been most consistently attractive to left of center parties. But more recently you have many people on the left casting doubt on that kind of policy and, instead, joining the right in adopting neoliberal globalization programs. The left has invented "progressive competitiveness," the Third Way, or neoliberalism with a human face.

At first glance, Keynesian and neoliberal strategies seem diametrically opposed. The first, as we all know, involve state intervention, what right wing critics like to call "tax and spend," for the purpose of increasing demand, stimulating investment by stimulating consumption. The other strategy, call it left neoliberalism, assumes that it's precisely Keynesian tax and spend policies that destroyed productivity and profitability, and propelled the world economy into a prolonged downturn after the postwar boom.

Both these strategies have demonstrably failed to overcome the inherent contradictions of capitalism. The exceptional postwar boom-and make no mistake about it, it was exceptional-ended more than a quarter of a century ago, so even if we give Keynesian strategies the credit for it, we have to concede that they couldn't sustain it. This has led many economists, right and left, to adopt what Brenner calls the "contradictions of Keynesianism" view. Reduced to its fundamentals, the "contradictions of Keynesianism" view is that Keynesian demand-management produced the long postwar boom by solving the problem of underconsumption but was self-undermining in the long run. By adopting policies to stimulate demand, this argument says, it strengthened the position of labor against capital and ended up by squeezing profits, thereby discouraging investment. The apparently inevitable response, then, was a swing of the pendulum to neoliberalism.

Brenner makes a devastating argument against explanations of the downturn that blame it on the strength of labor and its squeeze on profits. He shows in great empirical detail that the long downturn wasn't, and couldn't have been, caused by labor. He points out, among other things, that victories by labor, which tend to be relatively localized, can't in general account for system-wide crises. They certainly can't account for the prolonged and universal downturn that affected all economies at roughly the same time and at the same pace, in spite of all the many variations in their labor regimes or their configurations of class power. And he shows that at the onset of the downturn, labor conditions weren't that great anyway.

But neoliberalism hasn't provided the answer either. The neoliberal strategies that came in response to the downturn and were supposed to correct the failures of Keynesianism are now failing even more 
spectacularly. ${ }^{6}$ And we still have to confront the fact that so many different economies, with so many different institutional and political configurations, have suffered the same fate.

So we seem to be driven to an odd conclusion: it begins to appear that Keynesianism and neoliberalism are simply two sides of the same coin. The "contradictions of Keynesianism" view seems to suggest that both strategies, Keynesian and neoliberal, are counter-cyclical in their intentions, but each for a different phase of the cycle. On the face of it, that may seem an unhelpful conclusion. On second thought, though, maybe it does have the virtue of expressing some kind of reality. But instead of saying that what was right for one period was wrong for another, or that Keynesianism fell victim to its own success, it might have been better to say that both phases-the Keynesian and the neoliberal-represent the same underlying contradiction. The successive failures of both strategies reflect the same fundamental reality, which neither is prepared, or able, to confront.

The point I want to make, then, is that these strategies have failed not for antithetical reasons but for the same reason. However opposed these two strategies may seem in principle, the fact is that their underlying assumptions are fundamentally the same. In a way, both are based on the same false assumption: that if there is a contradiction in capitalism, it manifests itself simply at the level of the business cycle. That means, in the final analysis, that the contradictions of capitalism are benign or at least manageable.

In a way, both also seem to assume that we just need to strike the right balance between classes. It's true that neoliberalism gives a one-sided advantage to capital and blames crisis on things like unreasonable wage demands or inflexible labor markets and practices, while Keynesianism is more generous to labor, at least to the extent that it treats high employment and decent wages as essential sources of consumer demand. But neither this difference nor the others I've mentioned change the fact that both Keynesianism and neoliberalism are operating only at the level of the surface contradiction and never probe beneath it.

At bottom, the common ground of these strategies is that both are looking for ways to enhance market opportunities, to enable the market to function at its best, or to enable people to make the most of it. Neoliberals may seek to do it by deregulating markets, while Keynesians subsidize demand. But since neither comes close to confronting the conditions that make people dependent on the market in the first place, neither touches the underlying contradiction.

Some social democratic governments have tried a different approach, in their efforts to give capitalism a "human face." In addition to enhancing market opportunities, they may try to obstruct, or threaten to obstruct, the opportunities of capital—by measures such 
as social clauses, or the "Tobin tax"-in order to guide capital into more humane, or at least less destructive, practices. ${ }^{7}$ But whether they adopt enhancement or obstruction strategies, the unclerlying assumption remains the same: the operative principle is always market opportunities, while market imperatives are left essentially untouched.

\section{Nothing Short of Revolution?}

The unavoidable conclusion seems to be that capitalism's contradictions are irreducible, and nothing short of abolishing capitalism itself will do the trick. Does this mean that the left should dismiss any politics short of revolution?

My answer is, of course not. What I've been talking about so far has been strategies that are based on false or misleading assumptions about capitalism, strategies based on the assumption that capitalist contradictions, if they exist at all, operate at the level of the business cycle and are basically manageable, if only we can find the right mechanisms. But if we acknowledge that there are fundamental and irreducible contradictions, and that they can't be reached by any such policy interventions, there's still a lot to be done, well short of socialist transformation, and even if our ultimate objective is socialism.

There are, for instance, two kinds of left strategy that make perfect sense within the constraints of capitalism. The first is what you could call protective strategies. These have been a necessary part of capitalism since the beginning. Capitalism, despite its material achievements, is by its very nature a disruptive and destructive way of organizing social life, because it subordinates all human goods to the imperatives of accumulation, because it inevitably dispossesses huge multitudes of people, and so on. Since it first began to manifest these consequences, people have looked for ways to prevent those disruptive effects from tearing apart the social fabric-like, for instance, the Elizabethan poor laws in sixteenth century England. We can add to those protective measures the provision of certain basic necessities like affordable housing, which capital is averse to providing.

So that's the first kind of non-transformational strategy that makes sense within the constraints of capitalism. Another, more oppositional kind of non-transformational politics came with the development of industrial capitalism and with the growth of a mass proletariat: the struggle over the terms and conditions of work.

Now these two kinds of politics-the struggle for social provision and the class struggle over the terms and conditions of work-are indispensable under capitalism in all its forms. Capitalism will, needless to say, always and necessarily, mean the exploitation of workers, unrelenting attempts to intensify exploitation, to increase the gains that capital can extract from workers, and this will always, and neces- 
sarily, mean a fundamental antagonism of interest between capital and labor. So struggles over the terms and conditions of work are always necessary and always appropriate.

Capitalism will also, always and necessarily, have socially destructive effects, and people will always have to struggle to find ways of limiting or compensating for them. The scope of those protective struggles also has to encompass resistance to a very wide range of oppressions apart from class exploitation-racial, sexual, national oppressions, and so on-which intersect with and are reinforced by capitalist exploitation, and, of course, the ecological destruction inevitably caused by this accumulation-driven system must also come within their reach. In fact, as capitalism becomes truly global, as it draws the whole world, all human practices and the natural environment, into the orbit of its systemic contradictions, as it reproduces on a global scale its original logic of dispossession and polarization, the need for struggles of this protective kind is increasing all the time.

These kinds of objectives seem to me essentially unproblematic. I don't mean that there are no problems associated with them, or that capitalism can happily coexist with them. What I mean is that struggles for social provision and for improvements in the terms and conditions of work need not be based on any problematic assumptions about how capitalism works. They're not, at least at their best, based on illusions about the possibility of a capitalism free of basic contradictions. On the contrary, they take those contradictions for granted, dealing with the palpable effects of capitalism, limiting the damage as much as they can, providing safety nets, and when they can't limit the damage, picking up the pieces.

And, by the way, here's a reason for preferring Keynesian policies to their available alternatives, even if we recognize their limitations as counter-cyclical strategies: we can just look at them in the same way as we look at protective mechanisms in general, not so much as ways of correcting capitalist contradictions but just as redistributive policies, or as a way of improving public services, or employing more people simply because that's a good thing to do, especially if they're employed directly in the provision of public services.

\section{Competition and Class}

How, then, are these political questions affected by the way we perceive the relation between competition and class? In particular, if we adopt something like Brenner's conception of "horizontal" and "vertical" relations, does it mean that class struggle is relegated to the margins of left politics?

I mentioned before that some people on the left have objected to Brenner's focus on horizontal relations, the relations of competition among capitals, at the expense (they maintain) of vertical 
relations and class struggle. I suggested that I disagreed with that objection. I now want to take this point further and to say that, far from arguing against the importance of class struggle, that analysis argues strongly in favor of it.

Let's take a closer look at the connection between relations of competition among capitals and the relation between capital and labor. We've already seen how Brenner refutes those explanations of the downturn that blame it on a profit squeeze by labor. But I want to look at the question at a somewhat higher level of abstraction.

I have no doubt that as an orthodox Marxist I ought to be telling you, in the language of value theory, that capitalism is constituted by both horizontal and vertical relations, both relations among capitals and relations between capital and labor, and that we can't separate these two sets of relations, except analytically. At one level all this is obviously true. It's obviously true, for instance, that capital itself is produced by alienated labor, the labor of workers who are forced to sell their labor-power for a wage. In other words, capital derives from the appropriation of surplus value produced by workers.

It's also obviously true that the compulsions that force capital to compete, accumulate, and expand are inevitably expressed in the intensification of exploitation, and this obviously has consequences for class struggle. It's obviously true that especially when capital buys the labor-power of a free worker for a contractually fixed period of time, which is typical in mature capitalist systems, the pressure to increase the productivity of labor is that much greater, because capital has to get as much surplus value out of the laborer as possible during that limited time. It's also obviously true that the general commodification of labor-power is the basic and indispensable condition for generalizing market imperatives. The market can't become the universal regulator of the economy unless and until commodified laborpower becomes the more or less universal form of labor. In all these ways, competition and class relations are inseparable.

But here things start to get a bit tricky. We may have no trouble understanding how class and competition are intertwined in a mature capitalist society. But that's not the same as understanding what determines the imperatives of competition in the first place. It's not so easy to demonstrate that these imperatives are constituted by the relation between capital and labor.

Before dedicated socialists recoil in shock and horror, let me explain what $I$ mean. First, market dependence and market imperatives historically predated the proletarianization of labor. They predated the general commodification of labor power. In certain specific conditions, direct producers who were not completely dispossessed were nonetheless market-dependent. And second, market imperatives could continue to exist even if we eliminated the vertical division 
between capital and labor, the division between profits and wages, by giving workers back possession of the means of production. I'll spell this out a bit in a minute, but let me emphasize that I really do mean to say what I seem to be saying: market imperatives are not, in the first or last instance, dependent on the relation between capital and wage labor.

To elaborate the historical point, I'll just refer you to Brenner's historical work and what he says about the original conditions of market-dependence, though I'm making some connections that he doesn't explicitly make and drawing some strategic conclusions from them that he doesn't. Anyone interested in following the historical development of market-dependence can look at Brenner's essays in the so-called Brenner Debate. ${ }^{8}$

For our purposes, the important point is that he shows how economic units became market-dependent, in historically unprecedented ways, not because of the relation between capital and labor but before the widespread proletarianization of the work-force and as a precondition to it. In the specific property relations of early modern England, landlords and their tenants alike became dependent on the market for their self-reproduction and hence subject to the imperatives of competition and increasing productivity, whether or not they employed wage labor.

The crucial point here is that market-dependence, and the imperatives of competition that went with it, did not depend on the complete separation of the producers from the means of production. The essential condition was separation from non-market access to the means of subsistence, the means of self-reproduction. A tenant could, for instance, remain in possession of land, but his survival and his tenure could nonetheless be subject to market imperatives, whether he employed wage labor or was himself the direct producer. This kind of market-dependence was a cause of complete dispossession, a cause, not a result, of the expropriation of the English peasantry. People in possession of land were driven off the land not just by direct coercion but also by the operation of economic forces, the forces of an increasingly competitive market. So a mass proletariat was the result, not the cause, of those market imperatives.

This means, among other things, that the pressure to increase labor productivity wasn't originally caused by the relation between capital and wage labor. If anything, the reverse is true: the pressure to increase labor productivity brought about the generalized relation between capital and wage labor which we now regard as essential to capitalism. The capital/wage labor relation characteristic of a mature industrial capitalism, once established, certainly increased the need to revolutionize the technical forces of production, but we can't understand the emergence of that mature form without understanding the imperatives that preceded it. 
At any rate, here we have a historical case in which the market-dependence of producers, with or without wage labor, subjected them to the imperatives of competition. This provides at least a historical reason for thinking that we miss something fundamentally important about market dependence, market imperatives, and capitalist competition if we fail to recognize the ways in which they're not connected to the relation with wage labor, as well as the ways in which they are. The fact that market-dependence and competition preceded proletarianization tells us something about the relations of competition and their autonomy from the relations between capital and labor. It means that producers and possessors of the means of production, who are not themselves wage laborers, can be market-dependent without employing wage labor. In other words-and this is the basic theoretical point-market-dependence and competition give rise to the imperatives of accumulation and innovation even in the absence of exploitation of labor by capital, while in the absence of competition, no form of exploitation will have those effects. This clearly has implications for the pressures that affect capital even abstracted from its relation to wage labor.

But I want to go beyond that claim. The fact that market dependence can exist without complete dispossession of the direct producers has other implications. For instance, it tells us something about the impossibility of so-called market socialism. I think market socialism is impossible-I think the term market socialism is a contradiction in terms-because, even in the absence of a class division between capital and labor, even if the means of production are returned to the direct producers, as long as the market regulates the economy there will always be imperatives of accumulation and competition, these imperatives will take precedence over social needs and well being, and there will always be exploitation of labor-not to mention the ecological damage that inevitably goes with a system driven by those imperatives.

Once the market becomes an economic "discipline" or "regulator," once economic actors become market-dependent, even workers who own the means of production, individually or collectively, will be forced to respond to the market's imperatives-to compete and accumulate, to exploit themselves, and to let so-called "uncompetitive" enterprises and their workers go under. (Marx, by the way, suggested just this possibility in a discussion of workers cooperatives and how they would be self-exploiting in the presence of market imperatives.) To the extent that these competitive pressures demand the intensification of labor to maximize labor productivity, hierarchical relations in the process of production will be generated even in the absence of vertical relations between classes. And it even seems likely that the end result would be to reproduce 
the vertical relations of class. Just as market imperatives expropriated direct producers in the early days of capitalism, so they could have a similar effectin "marketsocialism."

\section{Political Consequences}

If market dependence and market imperatives are in some important ways independent of the relation between capital and labor, what does this add up to politically? What political implications should we draw from the independence of horizontal relations? Does it, for instance, mean that left politics should concentrate on improving "competitiveness" rather than on militant class struggle?

A common view, not least on the left today (for example, in the "contradictions of Keynesianism" view) is that too much class militancy is counter-productive, that by undermining the profitability of capital it undermines employment and social provision. But if there is an irreducible contradiction of market dependence in the relation among capitals, which is independent of the relations between capital and labor, we may draw a very different conclusion. We may conclude that there is no such obvious reason for restraining militant struggle.

If the dynamics of competition can operate even in the absence of any class division between capital and labor, it seems to follow that, where there is such a class division, the underlying competitive dynamic will operate no matter what the configuration of class power may be. So if competition is the focal point, the mechanism, of a fundamental contradiction, if competition is not just the mechanism of capitalist dynamism but at the same time a mechanism of stagnation and downturn, that fundamental contradiction is irreducible and it can't be circumvented, or even significantly modified, by any kind of class relation between capital and labor.

This is certainly not to say that class victories and defeats have no effect on capitalist profitability. But an analysis like Brenner's suggests that the connections are weaker than the conventional view allows. The point isn't that capitalist profits aren't affected by class struggle. It's that even in the absence of a squeeze on profits by class struggle, the contradiction in the relations among capitals will still bring about crisis, and capital will still squeeze workers.

I'm sure it's old news to socialists that there is a dual contradiction in capitalism, but I think that much of what passes for left politics these days seems to proceed on the assumption that there's nothing fundamentally contradictory or problematic in the relation among capitals. For example, pessimistic socialists seem to be giving up altogether on the grounds that there's now an increasingly unified global capitalist class which renders states and working classes helpless. Optimistic social democrats and advocates of the "Third Way" think they can achieve some humane kind of competitiveness, while 
the neo-Keynesian left seems to be suggesting that we can avoid the contradictions of capitalism if only we can strike the right balance in the class relation between capital and labor. What I'm arguing instead is that if we understand how capitalist contradictions are independent of class relations, we'll also understand the critical importance, the indispensability, and the possibilities of militant class struggle.

I'm trying to emphasize both the ways in which competition and class are separate and the ways in which they're inextricably linked. Both sides of the equation have to be kept in mind in devising our oppositional politics. On the one hand, the dependence of capital on labor, the simple fact that labor produces capital, the fact that the generalization of market imperatives does depend on the general commodification of labor-power-all these things mean that class struggle will always be the basic and necessary condition of any socialist transformation. And if anything, the independent contradictions of competition are a source of capitalist vulnerability, which increases, not decreases, the opportunities for transformational struggles.

On the other hand, there is a great deal to be done short of a socialist transformation. If we focus on the irreducible contradiction in the relations among capitals, which is there whatever the relations between capital and labor, there really is no reason to place limits on class struggle in pursuit of social protection and workplace advances, and they should be pursued as militantly as possible-both to achieve immediate reforms and to enhance class consciousness and organization for more long-term transformational struggles. The simple point is that they don't have to be constrained by the assumption that they are the ultimate source of the problem. They neither create, nor can they resolve, the contradictions in the relation among capitals.

As for what lies between protective or maintenance strategies and real transformational struggles-well, that's the hard part. But at least a few things are pretty clear. We may not know exactly what to do, but we should at least know what not to do. It makes no sense at all to pursue strategies that pull the economy ever further into the intensifying contradictions of the global economy-like deregulatory and export-led strategies beloved by the World Bank and the IMF, which simply deepen the contradictions of market-dependence.

The best that socialists can do is to aim as much as possible to detach social life from market-dependence. That means striving for the decommodification of as many spheres of life as possible and their democratization-not just their subjection to the political rule of "formal" democracy but their removal from the direct control of capital and from the "impersonal" control of market imperatives, which subordinate every human need and practice to the requirements of accumulation and profit-maximization. If that seems uto- 
pian, just consider how unrealistic it is to adopt a strategy of exportoriented competitiveness in a crisis-ridden global economy with an irreducible structural tendency to overcapacity.

But it's not my objective to outline policy solutions. My main point is simply that there can be struggles and objectives short of a socialist transformation, but there can't be such a thing as a Third Way. There really is no middle ground between capitalism and socialism.

That's not a paradox. It simply means that all oppositional struggles-both day-to-day struggles to improve the conditions of life and work, and struggles for real social change-should be informed by one basic perception: that class struggle can't, either by its presence or by its absence, eliminate the contradictions in the capitalist system, even though it can ultimately eliminate the system itself. This means struggling for every possible gain within capitalism, without falling into the hopeless trap of believing that the left can do a better job of managing capitalism. Managing capitalism is not the job of socialists, but, more particularly, it's not a job that can be done at all.

\section{NOTES}

1. Originally in "From Opportunity to Imperative: The History of the Market," Monthly Rewiew, July-August 1994, pp. 14-40, and most recently in The Origin of Capitalism (New York: Monthly Review Press, 1999).

2. Such arguments, including Marxist versions, are discussed in The Origin of Capilalism.

3. Brenner, "The Economics of Global Turbulence," New Left Review 229 (May-June 1998), p. 10.

4. An account of this basic mechanism similar to Brenner's can be found in "How the mighty are falling," Financial Times, November 30, 1998. But this is just the kernel of Brenner's analysis, which attempts to explain not only the basic mechanism of overproduction/overcapacity and the consequent fall in profitability but also why these continued to be reproduced in the long downturn, keeping profitability from recovering for such a long time. David McNally, in the June issue of MR, briefly summarizes the argument and elaborates on some of the ways in which the tenclency to overcapacity analyzed by Brenner is related to wider trends in the global economy.

5. Some of the criticisms of Brenner on this score may have more to do with the anonymous editorial introduction to his analysis, and its somewhat misleading account of his argument (not to mention its provocatively fulsome praise of Brenner), than with the analysis itself.

6. Calling neoliberalism a failure will no doubt seem odd to those who regard the U.S. economy as a brilliant success. For a corrective to that triumphalism, see Doug Henwood's piece in this year's summer issue of MR.

7. I owe this point to Gerard Greenfield, who sent me, by e-mail, an extremely interesting and fruitful argument elaborating in a new way my distinction between the market as opportunity and as imperative, which I hope he will develop and publish.

8. Eds. T.H. Aston and C.H.E. Philpin, The Brenner Debate: Agrarian Class Structure and Economic Development in Pre-Industrial Europe (Cambridge, 1985). 